\title{
SUMMERING AND BREEDING RECORDS OF BONAPARTE'S GULL NEAR BIGGAR, SK
}

WAYNE E. RENAUD, 9 Oakwood Avenue N., Mississauga, ON, L5G 3 L6 and ROBERT A. WAPPLE, \#740-4th Street E., Saskatoon, SK, S7H 1K2

On 12 June 1998, I (WER) noticed a small flock of swans resting on the far shore of the northern tip of Richmond Lake, $4 \mathrm{~km}$ sw of Biggar. On a hunch that they might be Trumpeters, I stopped and approached slowly on foot. At 150 $\mathrm{m}$, they took flight, and with them, two adult Bonaparte's Gulls flushed and began foraging over the marsh. After diving and feeding in a leisurely fashion at distances as close as $10 \mathrm{~m}$ for approximately 20 minutes, one gull circled upwards, flew southeast across a shrubcovered peninsula and disappeared from view over Richmond Lake.

I quickly moved to a high ridge that overlooks the lake to confirm the identity of the swans. The swans had fled, but one of the gulls was again located with binoculars. It spiralled downward over a large alkali flat laid bare by seasonal drought, and gently landed on a dry tussock of Alkali Grass (Puccinellia nuttalliana) approximately $100 \mathrm{~m}$ offshore. After standing, then turning several times, it settled, much to my amazement, onto a nest. It was not possible to determine the number of eggs because of the distance from the nest. Other tussocks were scanned for signs of nests, but none was found, nor were any other Bonaparte's Gulls seen in that immediate area. On returning to the vehicle, I again noted the other adult actively feeding over

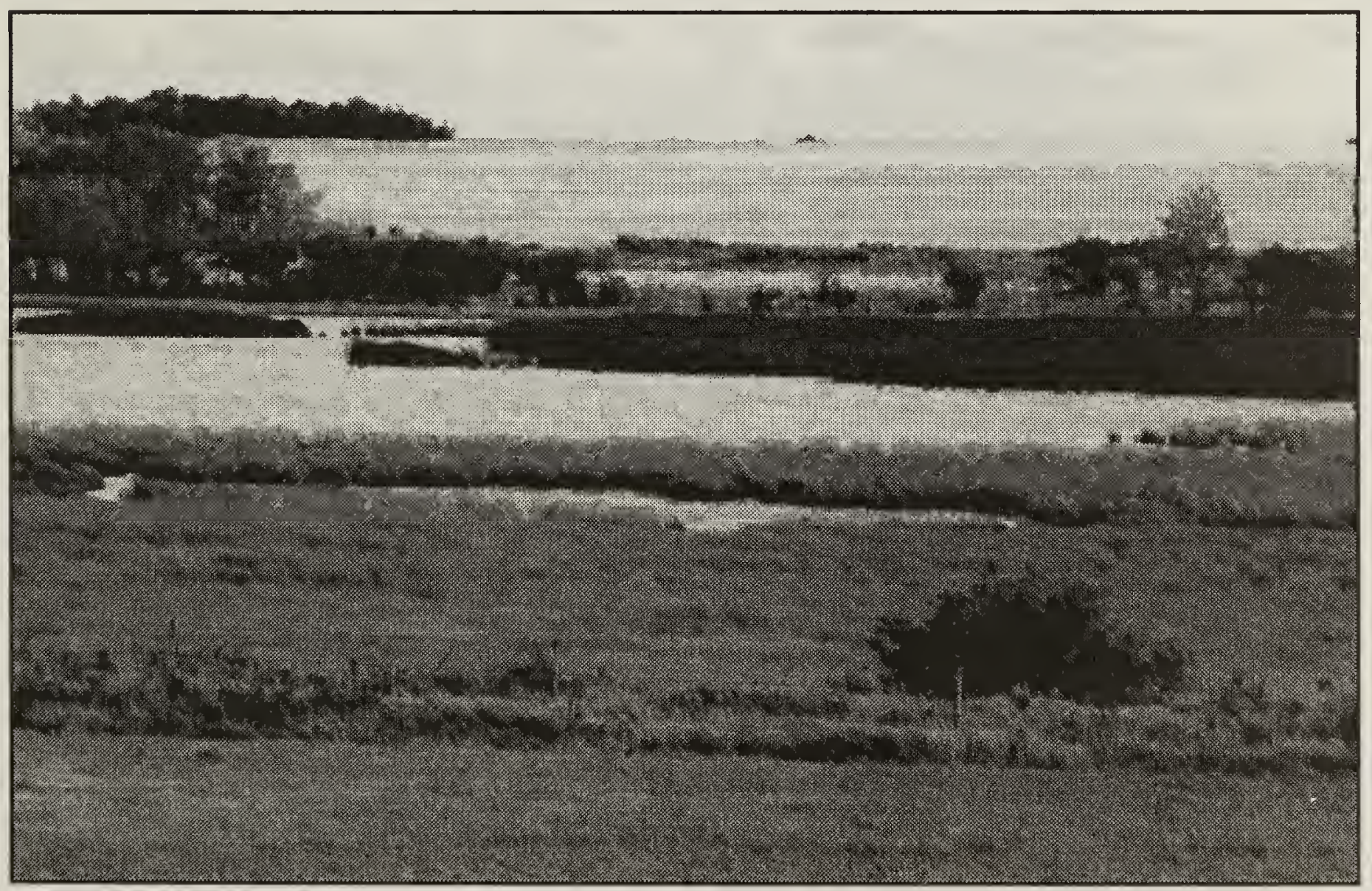


the marsh where the pair had first been seen.

On 25 June, Robert Wapple again located the adult incubating on the nest. He also found 11 other adult Bonaparte's Gulls casually feeding in the marsh north of Richmond Lake. On 7 July after several heavy rainstorms, Guy Wapple found the entire mudflat flooded and no trace of the nest. Two adult Bonaparte's Gulls, assumed to be the original pair, were feeding in the marsh. In all probability, the nest was a failure.

All previous summer (June and July) records of Bonaparte's Gulls in the Rosetown-Biggar area were reported within an area $6 \mathrm{~km}$ in diameter bounded by Biggar Sewage Lagoon, Biggar Lake and Richmond Lake. The first sighting was an adult seen with 100 Franklin's Gulls on Biggar Lake on 17 July 1975. The second was on 4 July 1982, when two adults and a sub-adult were seen on Biggar Sewage Lagoon. The following day, the number had increased to two adults and seven sub-adults, and on 16 July there were only two subadults. Other summer records of adults include one on Biggar Sewage Lagoon on 5 June 1988, a flock of four on Biggar Lake (100 m se of Richmond Lake), 10 on Biggar Sewage Lagoon on 4 June 1990 , and eight adults at the same location on 22 July.

Summer records of Bonaparte's Gull from other non-breeding areas of Saskatchewan show a preponderance of 1st-year immatures as compared to adults. ${ }^{3,11,13}$ The high ratio of adults (28) to sub-adults (7) in these records may reflect this area's relatively close proximity to the southern edge of the known provincial nesting range (Fig. 1).

In Saskatchewan, the southern edge of the Bonaparte's Gull's breeding range closely parallels the southern edge of the Southern Boreal Forest Vegetation Zone (Fig. 1). ${ }^{15}$ This is to be expected, as the typical breeding habitat of Bonaparte's Gull is most often described as "muskeg-dominated conifer forests, often near lakes and rivers" and the typical nest location as "a coniferous tree in the vicinity of a muskeg lake or pond; rarely on the ground or in marsh vegetation". 1, 6 Salt and Salt commented that Bonaparte's "have been reported nesting in the rushes of a marsh". ${ }^{14}$ This was later verified by the discovery of this species nesting in a Franklin's Gull colony at Loutit Lake in Alberta nw of Lake Athabasca. ${ }^{4}$ The earliest known report of the breeding of Bonaparte's Gulls on a prairie lake was made by Raine who shot three adults and on June 1891, noted "a few pairs . .. in company with herring gulls, avocets and common tern on an island in a small lake north of Rush Lake, Sask". ${ }^{12}$ This record, later cited by Macoun and Macoun, Thompson and Bent, has been discounted by Houston. $2,7,10,18$

In Saskatchewan, there is ample evidence that a small but significant portion of Bonaparte's Gulls may, in fact, breed in a variety of habitats in parklands and prairies, distant from the boreal marshes and bogs with which they are usually associated. To date, the published extralimital breeding locations have been confined to the Aspen Parkland Vegetation Zone, the most intensively studied being "Lamotte's Swamp" north of Jackfish Lake (Fig. 1), where from one to three pairs and five confirmed breeding records were reported in eight years from 1930 to 1970. 7,16,17 In fact, a nest with three eggs and the associated adults were collected by Fred Lahrman at that location and it is ironic that they later became a part of a "typical" marsh diorama at the Saskatchewan Museum of Natural History. 7,8 
Figure 1. Natural vegetation zones, breeding range of Bonaparte's Gull in Saskatchewan (cross-hatching) and locations of extralimital breeding records reported in this article. Map adapted from Atlas of Saskatchewan and Atlas of Saskatchewan Birds. ${ }^{5,15}$

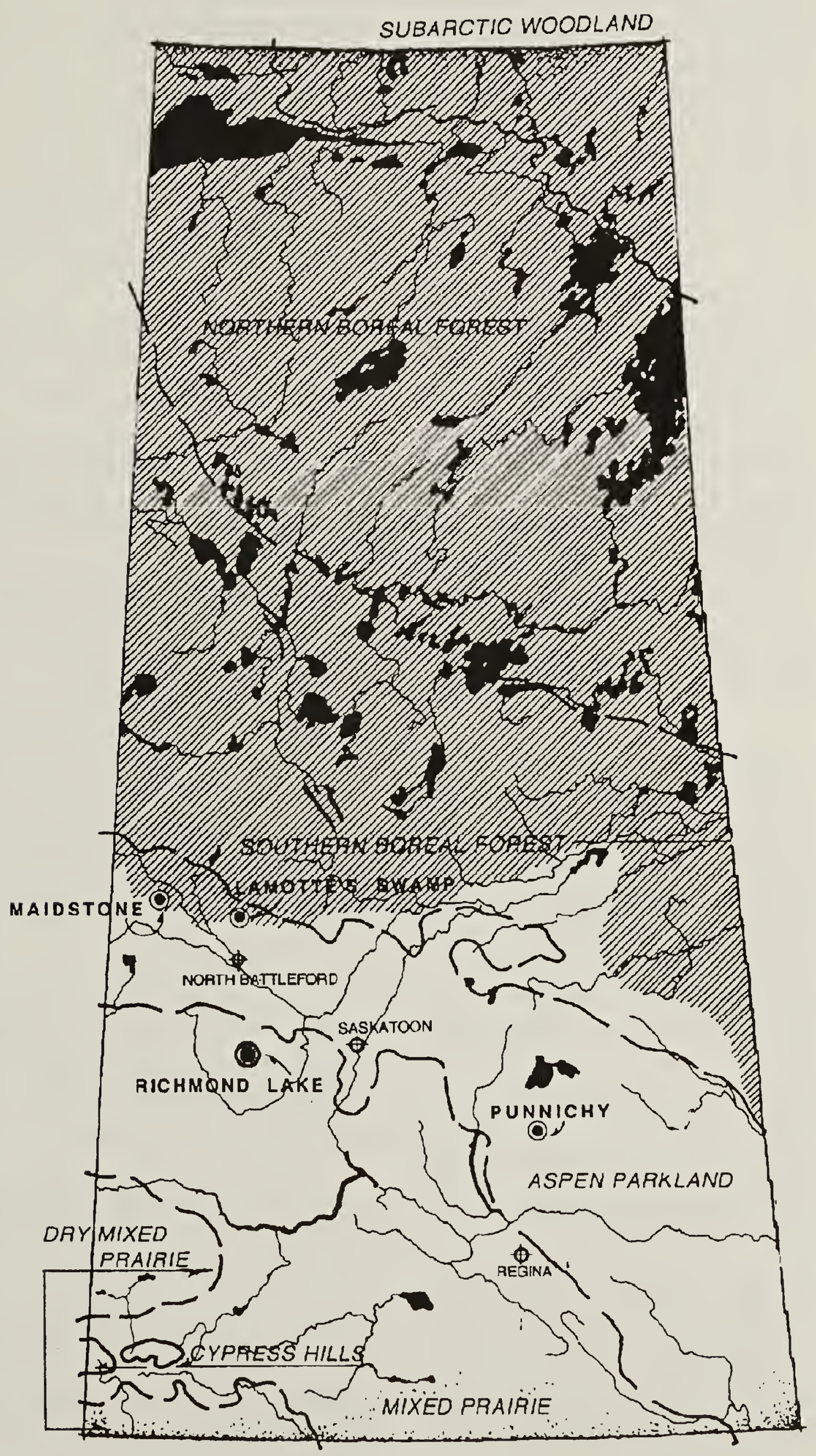


Three additional Aspen Parkland nest locations were reported by Lamont. ${ }^{9}$ The first two were near Maidstone: one at Low Lake, located $20 \mathrm{~km}$ north and $6.9 \mathrm{~km}$ west of Maidstone, where Dan Lamont recalled finding Bonaparte's Gulls nesting in the early 1930s, and the other on a mudflat of a temporary slough $24 \mathrm{~km}$ north and $4.8 \mathrm{~km}$ west of Maidstone on 10 June 1978. ${ }^{9}$ The third record (undated) from the Touchwood Hills near Punnichy, consisted of nine newly-fledged young being fed by adults. ${ }^{9}$

This Richmond Lake breeding record is the first breeding record in the Mixed Prairie Vegetation Zone, and the second breeding record of a Bonaparte's Gull nesting on a mud flat, the first being the 1978 Maidstone record. The breeding records nearest to Richmond Lake are the Lamotte's Swamp and Maidstone records $(120 \mathrm{~km} \mathrm{n}$ and $140 \mathrm{~km} \mathrm{nnw}$ of Richmond Lake, respectively). ${ }^{15}$ To our knowledge, there are no confirmed breeding records for the Saskatoon area to the east.

In closing, we must stress that Bonaparte's Gulls can easily be missed if they are mixed in with even a few Franklin's Gulls. Future field work by other birders and biologists will undoubtedly lead to the discovery of more "atypical" nesting habitats and more "extralimital" breeding records of this unpredictable and versatile little gull.

\section{Baicich, P. J. and C.J.O. Harrison.} 1997. 1975. A Guide to the Nests, Eggs, and Nestlings of North American Birds. 2nd Ed. Natural World/Academic Press, San Diego, California. 347 pp.

\section{Bent A. C. 1963. Life Histories of} North American Gulls and Terns. (Reprint). Smithsonian Inst., U.S.A. National Museum Bull. \#135 (dated 1926). Dover Publications, Inc, New York, N.Y., U.S.A.
3. Callin, E. M. 1980. Birds of the Qu'Appelle, 1857-1979. Special Publication No. 13, Saskatchewan Natural History Society, Regina. 168 pp.

4. Francis, J. and K. Lumbis. 1979. Habitat relationships and management of terrestrial birds in northeastern Alberta. Canadian Wildlife Service, Edmonton. 365 pp.

5. Fung, K. Ed. 1999. Atlas of Saskatchewan. University of Saskatchewan, Saskatoon. 336 pp.

6. Godfrey, W. E. 1986. The Birds of Canada. Revised Ed. National Museums of Canada, Ottawa. 595 pp.

7. Houston, C. S. 1981. An assessment of Walter Raine and his Saskatchewan records. Blue Jay 39(3):168-181.

8. Lahrman, F.W. 1969. Bonaparte's Gull nesting at Glaslyn, Saskatchewan, 1969. Blue Jay 27(4):221.

9. Lamont, S. 1980. Atypical nest of Bonaparte's Gull. Blue Jay 38(1):44-45.

10. Macoun, J. and J.M. Macoun. 1909. Catalogue of Canadian birds. Ottawa Government Printing Bureau, Ottawa. $761 \mathrm{pp}$.

11. Nero, R.W. and M.R. Lein. 1971. Birds of Moose Mountain, Saskatchewan. Special Publication No. 7. Saskatchewan Natural History Society, Regina. $168 \mathrm{pp}$.

12. Raine, W. 1892. Bird Nesting in Northwest Canada. Hunter Rose and Co., Toronto.197 pp.

13. Roy, J. Frank 1996. Birds of the Elbow. Manley Callin Series No. 3. Saskatchewan Natural History Society, Regina. 325 pp. 
14. Salt, R.S. and J.S. Salt.1976. The Birds of Alberta. Hurtig, Edmonton. 498 pp.

15. Smith, A. 1996. Atlas of Saskatchewan Birds. Saskatchewan Natural History Society, Regina. 456 pp.

16. Symons, R.D. 1967. Hours and the Birds. University of Toronto Press, Toronto. 224 pp.
17. Symons, R.D. 1968. Atypical nesting of Bonaparte's Gull in Saskatchewan. Blue Jay 26(2):70-74.

18. Thompson, E.E. 1891. The Birds of Manitoba. In : Ernest Thompson Seton in Manitoba 1882 - 1892. 1980. Premium Ventures Ltd./Manitoba Naturalists Society, Winnipeg.

\section{RARE OR UNUSUAL BIRD SIGHTINGS FOR BEAVERHILL LAKE, $A B, 1996-2000$}

D.T. TYLER FLOCKHART, 43 Wentworth Crescent, St. Albert, AB, T8N 3G7, tylerflockhart @ hotmail.com

Beaverhill Lake, situated near Tofield, Alberta is one of the best birding spots in Alberta and western Canada. It has been compared to Point Pelee for its bird diversity and prime habitat. ${ }^{4}$ Designated as a RAMSAR site (a wetland of international significance) in 1987 , it boasts a list of nearly 300 bird species. ${ }^{4,15}$ Besides the thousands of Snow Geese that arrive each spring, the plethora of warblers that flit through the trees and the huge numbers of shorebirds that congregate on the mudflats, there are rare and unusual species recorded each year. This article lists the rare or unusual sightings from 1996-2000 in the Beaverhill Lake area.

The bulk of the following information comes from the Beaverhill Bird Observatory (BBO) located on the south shore of Beaverhill Lake (Figure 1). Here, the full-time summer staff conducts bird banding and a daily census from late April to late September, and keeps comprehensive records. The Beaverhill Lake Sight Records compilers have been Roy Fairweather or Kevin Kardynal and Gretchen Peterson during the report period. $6,7,8,9,12$ Other sightings are from birders who frequent the Beaverhill Lake area.

The area covered in this report is referred to by BBO as the Beaverhill Sight Records zone. It encompasses all of Beaverhill Lake as well as Aspen Poplar woods and pasture land surrounding the lake, and is bounded by Highway 16 (north), Highway 14 (south), Secondary Highway 834 (west), and Range Road 172 (east). 